\title{
CLINICAL COMPARATIVE STUDY BETWEEN INTRATHECAL DEXMEDETOMIDINE AND DEXAMETHASONE ON PROLONGING THE DURATION OF INTRATHECAL BLOCKADE IN LOWER LIMB ORTHOPEDIC SURGERY
}

\author{
By
}

\author{
Ahmed Abd El-Hamed Hassan, Ali Abd-Allah Al-Kumity, Alaa El-Deen \\ Mahmoud Sayed Ahmed and Ismaeil Abd El-Latif Shabaiek
}

Department of Anesthesia and Intensive Care, Faculty of Medicine, Al-Azhar University

Corresponding Author: Ahmed Abd El-Hamed Hassan,

Mobile: +201095305293, E-mail: ahmedabdelhamed@ azhar.edu.eg

\begin{abstract}
Background: Spinal anesthesia is safer than general anesthesia during lower limb operations; many studies have been concerned about prolonging the duration of spinal anesthesia by adding different adjuvants.

Objective: To compare the efficacy of intrathecal dexmedetomidine versus intrathecal dexamethasone in prolonging duration of spinal anesthesia, and postoperative analgesia, safety and hemodynamic stability.

Patients and methods: Our study was carried out on 60 patients of American Society of Anesthesiologists (ASA) physical status I or II, scheduled for orthopedic operation under spinal anesthesiadivided into A, B and C from March 2020 to November 2020. They were divided into 3 equal groups: Group A received $2 \mathrm{ml}$ bupivacaine $(0.5 \%)$ and $10 \mu \mathrm{g}$ dexmedetomidine in $1 \mathrm{ml}$ normal saline intrathecal, Group B received $2 \mathrm{ml}$ bupivacaine $(0.5 \%)$ and $4 \mathrm{mg}$ dexamethasone in $1 \mathrm{ml}$ normal saline intrathecal and Group Creceived $2 \mathrm{ml}$ bupivacaine $(0.5 \%)$ and $1 \mathrm{ml}$ normal saline Intrathecal. The study was carried out at Al-Azhar University Hospitals (Al- Hussein and Sayed Galal Hospitals).

Results: The present study showed statistically significant difference (P-value $<0.001)$ between the three groups according to time of motor and sensory regression. The regression time of block (both sensory and motor) were prolonged in A (sensory 359.50 \pm 20.32 , motor $319.00 \pm 21.06$ ) and B (sensory 199.75 \pm 18.22 , motor $170.00 \pm 20.00$ ) when compared to the C group (sensory $149.55 \pm 10.83$, motor 141.00 \pm 22.09 ). However, the duration was longest in A group among the three groups. According to amount of analgesic consumption postoperatively, there was significant decrease in amount in A group in comparison to B and C groups. The amount is insignificantly decreased in B group in comparison to C group. Regarding safety and hemodynamic stability there was no statistically significant difference between the three groups.

Conclusion: Dexmedetomidine had prolonging the duration of spinal anesthesia more than dexamethasone and control group with statistically significant difference between the three groups and provided prolonged postoperative analgesia compared to dexamethasone and control group.
\end{abstract}

Keywords: Intrathecal dexmedetomidine, Intrathecal dexamethasone, Spinal anesthesia.

\section{INTRODUCTION}

Orthopedic surgeries are very common and lower limb fractures occur in a lot of age groups, old age specially are at high risk and have a lot of morbidity and mortality with general anesthesia. So, regional techniques have come to take an 
upper hand in anesthesia over general anesthesia due to certain advantages like less chance of airway compromise and aspiration, facilitation of postoperative analgesia, benefit in some preexisting medical conditions and so on. However, postoperative pain control is a major problem because spinal anesthesia using only local anesthetics is associated with relatively short duration of action, and thus early analgesic intervention is needed in the postoperative period. A number of adjuvants, such as opioids and others have been studied to prolong the effect of spinal anesthesia. The addition of opioids to local anesthetic solution has disadvantages, such as pruritus and respiratory depression (Guptaet al., 2011).

One of these additives is dexamethasone, which has been proved in many studies to prolong the duration of peripheral blocks both in animal and human studies. Dexamethasone has antiinflammatory and analgesic action by inhibition of transmission in nociceptive $\mathrm{C}$ -fibers and neural discharge. When given as an additive in peripheral nerve blocks or in intrathecal anesthesia, it prolongs the duration of anesthesia (Shalu and Ghodki, 2017).

Dexmedetomidine is eight times more specific and highly selective $\alpha 2$ adrenoreceptor agonist compared with clonidine, that making it a useful and safe adjunct in diverse clinical applications (Ganesh and Krishnamurthy 2018).

The mechanism by which intrathecal a2-adrenoceptor agonists prolong the motor and sensory block of local anesthetics is by binding to presynaptic $\mathrm{C}$ fibers and postsynaptic dorsal horn neurons. Their analgesic action is a result of depression of the release of C-fiber transmitters and hyperpolarization of postsynaptic dorsal horn neurons (Nethra et al., 2015).

The prolongation of sensory effect may result from synergism between local anesthetic and $\alpha 2$-adrenoceptor agonist, while the prolongation of the motor block of spinal anesthetics may result from the binding of $\alpha 2$-adrenoceptor agonists to motor neurons in the dorsal horn Intrathecal $\alpha 2$-receptor agonists have been found to have antinociceptive action for both somatic and visceral pain (Routray et al., 2017).

The present work aimed to compare the effect of adding dexmedetomidine versus dexamethasone intrathecally as an adjuvant to $0.5 \%$ hyperbaric bupivacaine for prolonging the duration of spinal anesthesia, postoperative analgesiaand evaluate any possible side effects.

\section{PATIENTS AND METHODS}

This prospective randomized double blind clinical study was approved by the ethics committee in Al-Azhar University and patients' written informed consents were obtained.

The study was carried out at Al- Azhar University Hospitals (Al-Hussein and Bab El-Sharia) from March 2020 till November 2020.

This study included 60 patients of both sex, ages ranged from 20-50 years, ASA physical status I and II scheduled for lower limb orthopedic surgeries requiring spinal anesthesia. Patients were excluded from the study if they had major cardiac, respiratory, hepatic or renal diseases, hypersensitivity to used drugs, 
uncontrolled diabetes, neurological or psychological disorder that may affect communication with the patient, neuromuscular disorder or drug abuse interfered with sensations or motor power of lower limbs, body mass index $<30 \mathrm{~kg}$ per square meter, coagulopathy, or infection at the site of injection.

In pre-anesthetic room 18 G IV cannula was inserted and $10 \mathrm{ml} / \mathrm{kg}$ crystalloid solution as a preload was started. On arrival to OR all monitors were attached (noninvasive blood pressure, pulse oximetry, and five-lead ECG), Baseline readings were recorded.

All patients were prepared for spinal anesthesia using $2 \mathrm{ml}$ bupivacaine $(0.5 \%)$. The patients were randomly divided into three equal groups:Group A was administered $10 \mu$ gdexmedetomidine in 1 $\mathrm{ml}$ saline.Group Bwas administered $4 \mathrm{mg}$ dexamethasone in $1 \mathrm{ml}$ saline andGroup $\mathrm{C}$ was administered an additional $1 \mathrm{ml}$ of saline. After infiltration of the skin by $5 \mathrm{ml}$ lidocaine $2 \%$, intrathecal anesthesia was administered using a $22-\mathrm{G}$ spinal needle inserted into the L3-L4 space, with the patient in the sitting position with complete sterilization.. The patients were monitored for heart rate, arterial pressure, and oxygen saturation every 5 min after injection for $30 \mathrm{~min}$, and then every 15 min. Sensory block was assessed using pin prick every $2 \mathrm{~min}$, while the patient was supine till proper level was reached (T10 dermatome), and Bromage scale was measured to reach Bromage 3 before surgery (Rajesh et al., 2015).

Any decrease in heart rate below 60/min was treated with intravenous atropine $(0.01 \mathrm{mg} / \mathrm{kg})$, and any decrease in mean arterial pressure below $20 \%$ of the basal reading was treated by fluid bolus and $5 \mathrm{mg}$ intravenous increments of ephedrine. Pain postoperatively was assessed with visual analogue scale (VAS) between 0 and $10(0=$ no pain, $10=$ the most severe pain). If the VAS was $\geq 3$ patient received Ketolac (30 mg IV infusion) first, then VAS reassessed 15 minutes later, nalbuphine $(0.15 \mathrm{mg} / \mathrm{kg} \mathrm{IV})$ was given if (VAS) $\geq 3$ after giving Ketolac. VAS was been reassessed 15 minutes later to any rescue analgesic injection. Postoperative nausea and vomiting was managed if intolerable with ondansetron (4 mg) intravenously.

Statistical analysis: Results of the present study were statistically analyzed using SPSS version $20.0 \quad$ (IBM, USA).Quantitative data were expressed as mean \pm standard deviation (SD). Qualitative data were expressed as frequency and percentage. Numerical data were compared using A one-way analysis of variance (ANOVA) test followed by Post-hoc test, while categorical data were compared using Chi-square. The confidence interval was set to $95 \%$ and the margin of error accepted was set to $5 \%$. So, the p-value of $<0.05$ was considered significant. 


\section{RESULTS}

Regarding demographic data(age, sex, ASA, time of operation), there was no statistically significant difference between three groups. The findings of our study regarding male to female ratio $(80 \%)$, mean of ageof patients(34.8-33.0-36.1), ASA to ASA ratio (76.67\%) and mean of duration of operation (90.0-80.5-80.0) (Table 1).

Table (1): Comparison between three groups according to demographic data

\begin{tabular}{|c|c|c|c|c|}
\hline Demographic data & $\begin{array}{c}\text { Group A } \\
(n=20)\end{array}$ & $\begin{array}{c}\text { Group B } \\
(n=20)\end{array}$ & $\begin{array}{c}\text { Group C } \\
(n=20)\end{array}$ & $\begin{array}{c}\text { P- } \\
\text { value }\end{array}$ \\
\hline Age (years) Mean \pm SD & $34.80 \pm 8.88$ & $33.80 \pm 8.70$ & $36.10 \pm 9.68$ & 0.726 \\
\hline $\begin{array}{c}\text { Sex } \\
\text { Female }\end{array}$ & $4(20.0 \%)$ & $3(15.0 \%)$ & $5(25.0 \%)$ & \multirow{2}{*}{0.732} \\
\hline Male & $16(80.0 \%)$ & $17(85.0 \%)$ & $15(75.0 \%)$ & \\
\hline $\begin{array}{c}\text { ASA } \\
\text { I }\end{array}$ & $16(80.0 \%)$ & $15(75.0 \%)$ & $15(75.0 \%)$ & 0.911 \\
\hline II & $4(20.0 \%)$ & $5(25.0 \%)$ & $5(25.0 \%)$ & 0.410 \\
\hline Weight $(\mathrm{Kg})$ & $79.90 \pm 9.22$ & $79.50 \pm 7.55$ & $76.40 \pm 10.06$ & \multirow{2}{*}{0.118} \\
\hline Height $(\mathrm{cm})$ & $175.10 \pm 9.22$ & $172.20 \pm 7.49$ & $169.20 \pm 9.73$ & \\
\hline Duration of operation & $90.00 \pm 16.99$ & $80.50 \pm 18.02$ & $85.00 \pm 16.99$ & 0.231 \\
\hline
\end{tabular}

Regarding time of total sensory and motor block regression, there wasa statistically significant difference between three groups. The regression time of block both sensory and motor prolonged in A and $\mathrm{B}$ groups when compared to the $\mathrm{C}$ group. However, the duration was longest in A group among the three groups. This study showed that mean of time of sensory regression is (359.5-199.75149.55) for Groups A, B and C respectively. The mean of time of motor regression is (319.0-170.0-141.0) for Groups A, B and C respectively (Table 2).

Table (2): Comparison between three groups regarding time of sensory and motor block regression

\begin{tabular}{|c|c|c|c|c|c|c|c|}
\hline \multirow{2}{*}{$\begin{array}{l}\text { Groups } \\
\text { Sensory } \\
\text { and } \\
\text { Motor } \\
\text { block }\end{array}$} & \multirow[b]{2}{*}{$\begin{array}{c}\text { Group A } \\
(n=20)\end{array}$} & \multirow[b]{2}{*}{$\begin{array}{c}\text { Group B } \\
(n=20)\end{array}$} & \multirow[b]{2}{*}{$\begin{array}{c}\text { Group C } \\
(n=20)\end{array}$} & \multirow[b]{2}{*}{$\begin{array}{c}\text { ANOVA } \\
\text { p-value }\end{array}$} & \multicolumn{3}{|c|}{ Post HOC } \\
\hline & & & & & P1 & $\mathbf{P 2}$ & P3 \\
\hline \multicolumn{8}{|c|}{ Sensory block (min) } \\
\hline Mean \pm SD & $359.50 \pm 20.32$ & $199.75 \pm 18.22$ & $149.55 \pm 10.83$ & $<0.001$ & $<0.001$ & $<0.001$ & 0.001 \\
\hline \multicolumn{8}{|c|}{ Motor block (min) } \\
\hline Mean \pm SD & $319.00 \pm 21.00$ & $170.00 \pm 20.00$ & $141.00 \pm 22.09$ & $<0.001$ & $<0.001$ & $<0.001$ & $<0.05$ \\
\hline
\end{tabular}

P1: Comparison between Group A and Group B, P2: Comparison between Group A and Group, P3: Comparison between Group B and Group C 
Regarding time of request of first analgesic, there was a statistically significant difference between three groups. The requirement of analgesia significantly delayed in A group in comparison to $\mathrm{B}$ and $\mathrm{C}$ groups. $\mathrm{C}$ group was the earliest group in requirement of analgesia. Mean of first time of analgesia request was (293.5-178.4-125.0) for Groups A, B and C respectively (Table 3).

Table (3): Comparison between three groups according to time of request of first analgesic

\begin{tabular}{|c|c|c|c|c|c|c|c|}
\hline Groups & & & & & \multicolumn{3}{|c|}{ Post HOC } \\
\hline $\begin{array}{l}\text { of request } \\
\text { of first } \\
\text { analgesic }\end{array}$ & $(n=20)$ & $(n=20)$ & $(n=20)$ & p-value & P1 & $\mathbf{P 2}$ & P3 \\
\hline Mean \pm SD & $293.50 \pm 15.57$ & $178.40 \pm 19.26$ & $125.00 \pm 17.47$ & $<0.001$ & $<0.001$ & $<0.001$ & $<0.001$ \\
\hline
\end{tabular}

P1: Comparison between Group A and Group B, P2: Comparison between Group A and Group C, P3: Comparison between Group B and Group C

There was a statistically significant difference between three groups regarding total amount of analgesic consumption there was significant decrease in amount in A group in comparison to $\mathrm{B}$ and $\mathrm{C}$ groups. The amount insignificantly decreased in B group in comparison to $\mathrm{C}$ group. This study showed that mean of number of analgesic injections were (1.93.45-3.0) for Groups A, B and C respectively (Table 4).

Table (4): Comparison between three groups according to total amount of analgesic consumption

\begin{tabular}{|c|c|c|c|c|c|c|c|}
\hline \multirow{2}{*}{$\begin{array}{l}\text { Groups } \\
\text { amount of } \\
\text { analgesic use }\end{array}$} & \multirow{2}{*}{$\begin{array}{c}\text { Group A } \\
(n=20)\end{array}$} & \multirow{2}{*}{$\begin{array}{c}\text { Group } \\
\text { B } \\
(n=20)\end{array}$} & \multirow{2}{*}{$\begin{array}{c}\text { Group C } \\
(n=20)\end{array}$} & \multirow{2}{*}{$\begin{array}{c}\text { ANOVA } \\
\text { p-value }\end{array}$} & \multicolumn{3}{|c|}{ Post HOC } \\
\hline & & & & & P1 & P1 & P1 \\
\hline Mean \pm SD & $1.90 \pm 0.45$ & $3.45 \pm 0.51$ & $3.50 \pm 0.51$ & $<0.001$ & $<0.001$ & $<0.001$ & 0.758 \\
\hline
\end{tabular}

P1: Comparison between Group A and Group B, P2: Comparison between Group A and Group, P3: Comparison between Group B and Group C

According to patient's opinion toward pain control, there was a statistically significant difference between three groups. Number of patients with complete satisfaction was more in A group (65\%) in comparison to B group (40\%) and C group (15\%) only (Table 5).

Table (5): Comparison between three groups according to pain control satisfaction

\begin{tabular}{|c|c|c|c|c|}
\hline $\begin{array}{l}\text { Pain control Groups } \\
\text { satisfaction }\end{array}$ & $\begin{array}{c}\text { Group A } \\
(\mathbf{n = 2 0})\end{array}$ & $\begin{array}{c}\text { Group B } \\
(\boldsymbol{n}=\mathbf{2 0})\end{array}$ & $\begin{array}{c}\text { Group C } \\
(\boldsymbol{n}=\mathbf{2 0})\end{array}$ & $\begin{array}{c}\text { ANOVA } \\
\text { p-value }\end{array}$ \\
\cline { 1 - 3 } No satisfaction & $1(5.0 \%)$ & $7(35.0 \%)$ & $10(50.0 \%)$ & \multirow{2}{*}{$<0.01$} \\
\cline { 1 - 3 } Partial satisfaction & $6(30.0 \%)$ & $5(25.0 \%)$ & $7(35.0 \%)$ & \\
\hline Complete satisfaction & $13(65.0 \%)$ & $8(40.0 \%)$ & $3(15.0 \%)$ & \\
\hline
\end{tabular}


There was no statistically significant difference between three groups as regard the required doses of atropine and ephedrine. In our study, we used atropine
3 times for group A, 1 time for B and no time for $\mathrm{C}$ group. Regarding ephedrine, we used it 2 times for A, 1 time for B and 2 times for $\mathrm{C}$ group (Table 6 ).

Table (6): Comparison between three groups according to doses of atropine and ephedrine required

\begin{tabular}{|c|c|c|c|c|}
\hline Groups & $\begin{array}{c}\text { Group A } \\
(\mathbf{n = 2 0})\end{array}$ & $\begin{array}{c}\text { Group B } \\
(\boldsymbol{n}=\mathbf{2 0})\end{array}$ & $\begin{array}{c}\text { Group C } \\
(\boldsymbol{n}=\mathbf{2 0})\end{array}$ & $\begin{array}{c}\text { ANOVA } \\
\mathbf{p} \text {-value }\end{array}$ \\
\hline Atropine & $3(15.0 \%)$ & $1(5.0 \%)$ & $0(0.0 \%)$ & 0.153 \\
\hline Ephedrine & $2(10.0 \%)$ & $1(5.0 \%)$ & $2(10.0 \%)$ & 0.804 \\
\hline
\end{tabular}

There was no statistically significant difference between three groups as regards times of bradycardia and hypotension. In our study, bradicardia occurred 3 times for group A, 1 time for B and no time for $\mathrm{C}$ group. Regarding hypotension we faced it 2 times for $\mathrm{A}, 1$ time for $\mathrm{B}$ and 2 times for $\mathrm{C}$ group (Table 7).

Table (7): Comparison between three groups according to times of bradycardia and hypotension

\begin{tabular}{|c|c|c|c|c|}
\hline Groups & $\begin{array}{c}\text { Group A } \\
(\boldsymbol{n = 2 0})\end{array}$ & $\begin{array}{c}\text { Group B } \\
(\boldsymbol{n}=\mathbf{2 0})\end{array}$ & $\begin{array}{c}\text { Group C } \\
(\boldsymbol{n}=\mathbf{2 0})\end{array}$ & $\begin{array}{c}\text { ANOVA } \\
\text { p-value }\end{array}$ \\
\hline Bradycardia & $3(15.0 \%)$ & $1(5.0 \%)$ & $0(0.0 \%)$ & 0.153 \\
\hline Hypotension & $2(10.0 \%)$ & $1(5.0 \%)$ & $2(10.0 \%)$ & 0.804 \\
\hline
\end{tabular}

\section{DISCUSSION}

In this study, there was a significant prolongation of duration of spinal anesthesia with dexmedetomidine and dexamethasone with more effective postoperative analgesia; however dexmedetomidine is associated with the longest duration of anesthesia and most effective postoperative analgesia. Dexmedetomidine added to intrathecal bupivacaine was associated with a longer duration of the sensory blockade compared with addition of dexamethasone in lower limb orthopedic surgeries under spinal anesthesia. In addition, it caused longer duration of motor block. Meanwhile, addition of dexamethasone prolonged duration of sensory block. Postoperatively, dexmedetomidine produced longer duration of analgesia.
Frequency of adverse events was limited in all groups.

Dexmedetomidine's ability to prolong sensory and motor blockade could be explained by being a highly selective $\alpha 2$ adrenergic receptor agonist. In addition, it has a sedative, analgesic, perioperative sympatholytic, and hemodynamicstabilizing property. Moreover, it has the advantage of no respiratory depression. In the spinal cord, it activates $\alpha 2$-adrenergic receptors in the neurons of the superficial dorsal horn. It directly reduces pain transmission by reducing the release of pronociceptive transmitter, substance $\mathrm{P}$, and glutamate from primary afferent terminals, and by hyperpolarizing spinal interneurons by G-protein-mediated activation of potassium channels. The possible explanation of the effect of 
adding dexmedetomidine to intrathecal bupivacaine lies in its synergistic effect being selective $\alpha$ 2-adrenergic receptor agonist, which binds to the presynaptic $\mathrm{C}$ fibers and postsynaptic dorsal horn neurons. Thus, it produces analgesia by depressing the release of C-fiber transmitters, hyperpolarization of postsynaptic dorsal horn neurons; whereas bupivacaine as a local anesthetic acts by blocking sodium channels (Gupta et al., 2011).

The study results went in line with the study conducted by (Shukla et al., 2011) who compared dexmedetomidine versus magnesium sulfate added to intrathecal bupivacaine, and found that dexmedetomidine shortened the onset and prolonged the duration of spinal anesthesia. Another study proved superiority of intrathecal dexmedetomidine in comparison with clonidine and fentanyl, it provided prolonged motor and sensory block and reduced demand of additional analgesics (Solanki et al., 2013). The current study results were in agreement with the studies comparing clonidine and dexmedetomidine in different doses as adjuncts to bupivacaine which found the duration of sensory and motor block to be prolonged with dexmedetomidine compared with clonidine. Postoperative analgesia was comparable in these two groups and superior compared to bupivacaine alone (Al-Mustafa et al., 2013). Dexmedetomidine was tried as an adjunct to spinal bupivacaine through the intravenous route. It was found to prolong sensory and motor block with a good sedative effect (Kaya et al., 2010). Compared with midazolam, intravenous dexmedetomidine had prolonged sensory block and longer time to first request for postoperative analgesia, whereas duration of motor block was similar (Reddy et al., 2013). Similarly, premedication with intravenous dexmedetomidine is better than clonidine to provide intraoperative sedation and postoperative analgesia during bupivacaine spinal anesthesia for orthopedic lower limb surgery (Bajwa et al., 2011).

The previously mentioned studies as well as the current study confirmed safety and hemodynamic stability of dexmedetomidine, whether administered intravenously or intrathecally as an adjuvant to spinal bupivacaine anesthesia.

In this study, dexamethasone was found to prolong the sensory blockade and prolong the time to first call for analgesia when added to intrathecal bupivacaine compared with bupivacaine alone. Intrathecal dexamethasone as an analgesic could be explained by influencing prostaglandin production. The results of the current study regarding dexamethasone went in line with a study conducted by Bani-Hashem who reported an increase in the duration of sensory block associated with the addition of intrathecal dexamethasone (Bani-Hashem et al., 2011).

The study results showed that adding dexmedetomidine to intrathecal bupivacaine prolonged the sensory blockade duration by more than $100 \%$ compared with bupivacaine alone, although the sensory blockade duration was prolonged by $33.3 \%$ when adding dexamethasone to intrathecal bupivacaine. The cost effectiveness of dexmedetomidine versus dexamethasone is an issue of conflict, as tangible cost of 
dexmedetomidine is higher than dexamethasone. Yet, the intangible costs (hospital stay, wound infection, ICU stay if needed, antibiotics .... etc.) need to be considered in drug selection.

On the contrary to our study, there was no significant difference in motor block regression to Bromage 0 between the dexamethasone group and control (normal saline) group (Nashwa et al., 2014).

\section{CONCLUSION}

Addition of dexmedetomidine to intrathecal bupivacaine prolonged the duration of sensory and motor block, and prolongs postoperative analgesia compared with dexamethasone when added to intrathecal bupivacaine, with effective hemodynamic stability and limited frequency of adverse events in all groups.

\section{REFERENCES}

1. Al-Mustafa M. M., Badran I. Z., Abu-Ali H. M., Al-Barazangi B. A., Mossad I. M. and Al-Ghanem S. M. (2013): Intravenous dexmedetomidine prolongs bupivacainespinal analgesia. Middle East J Anesthesiology: 20: 225-231.

2. Bajwa S. J., Bajwa S. K., Kaur J., Singh G. and Arora V. (2011): Dexmedetomidine and clonidine in epidural anaesthesia: a comparative evaluation. Indian $\mathbf{J}$ Anesthesia: 55:116-1 21.

3. Bani-Hashem N., Hassan-Nasab B., Pour E. A., Maleh P. A., Nabavi A. andJabbari A. (2011): Addition of intrathecal dexamethasone to bupivacaine for spinal anesthesia in orthopedic surgery. Saudi J Anesthesia: 5:382- 386.

4. Ganesh M. and Krishnamurthy D. (2018): A comparative study of dexmedetomidine and clonidine as an adjuvant to intrathecal bupivacaine in lower abdominal surgeries. Anesthesia. Essays and Researches: 12: $539-545$.

5. Gupta R., Bogra J., Verma R., Kohli M., Kushwaha J.K. and Kumar S. (2011): Dexmedetomidine as an intrathecal adjuvant for postoperative analgesia. Indian $\mathrm{J}$ Anesthesia: 55:347-351.

6. Kaya F. N., Yavascaoglu B., Turker G., Yildirim A., Gurbet A., Mogol E. B. andOzcan B. (2010): Intravenous dexmedetomidine, but not midazolam, prolongs bupivacaine spinal anesthesia. Can J Anesthesia: $57: 39-45$.

7. Nashwa E., Heba I. N. andKarim G. (2014): The effect of adding dexmedetomidine versus dexamethasone on prolonging the duration of intrathecal bupivacaine in lower abdominal operations.AinShams Journal of Anesthesiology: 07:388-392.

8. Nethra S. S., Sathesha M., Aanchel D., Pradeep A. D., Harsoor S. and Devikarani D. (2015): Intrathecal dexmedetomidine as adjuvant for spinal anesthesia for perianal ambulatory surgeries. Indian J. of Anesthesia: 51:177-181.

9. Rajesh M., Suvarana K., Indu S., Taznim M. and Priyanka P. (2015): Difficult air way management and alternative from regional anesthesia. 
Indian Journal of Anesthesia: 59: 801806.

10. Reddy V. S., Shaik N. A., Donthu B. and Jangam V. (2013): Intravenous dexmedetomidine versus clonidine for prolongation of bupivacaine spinal anesthesia and analgesia: A randomized double-blind study. J Anesthesiology Clin Pharmacology: 29: 342-347.

11. Routary S., Rabinarayan D. and Bidhubhusan M. (2017): Comparison of intraarticulerlevobupivacaine and dexmedetomidine with ropivacaine and dexmedetomidine for postoperative pain management. AIMDR: 13: 120-131.

12. Shalu P. S. and Ghodki P. S. (2017): Dexamethasone efficacy in prolonging spinal anesthesia in elective CS.
Anesth. Essays and researches: 11: $321-325$.

13. Shukla D., Verma A. and Agarwal A. (2011): Comparative study of intrathecal dexmedetomidine with intrathecal magnesium sulfate used as adjuvants to bupivacaine. $\mathrm{J}$ Anesthesiology Clin Pharmacology: 27: 495-502.

14. Solanki S. L., Bharti N., Batra Y. K., Jain A., Kumar P. and Nikhar S.A. (2013): The analgesic effect of intrathecal dexmedetomidine or clonidine, with bupivacaine, in trauma patients undergoing lower limb surgery: a double-blind study. Anaesth.S Intensive Care: 41:51- 56. 


\section{در اسة عملية للمقارنة بين حقن الديكسمتيدومبدين

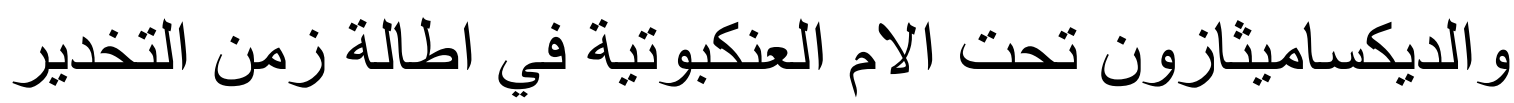

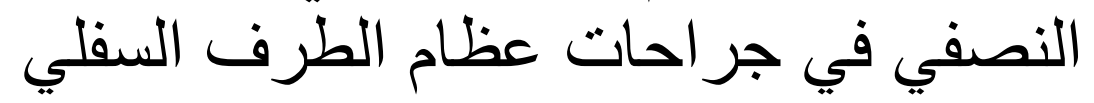

أحمد عبدالحميد حسن أحمد، علي عبدالله الكميتي، علاء الدين محمود سيد أحمد،

\section{إسماعيل عبداللطيف شبايك عيد}

قسم التخدير والرعاية المركزة، كلية الطب، جامعة الأزهر

E-mail: ahmedabdelhamed@azhar.edu.eg

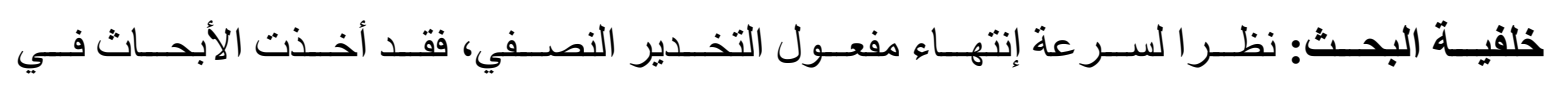

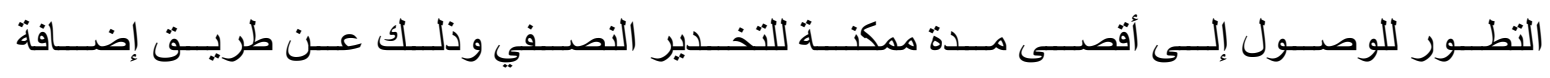

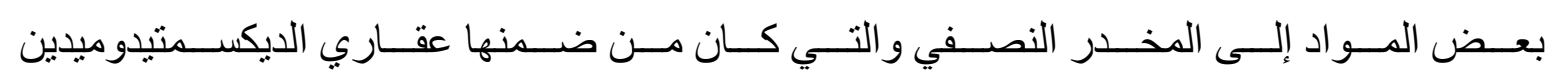
والديكساميثازون محل الدر اسة الحالية.

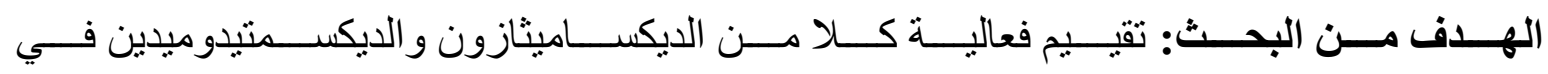

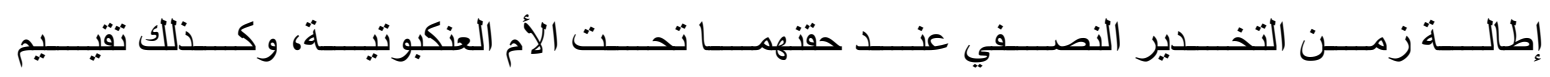
الاعر اض الجانبية لكل منهما.

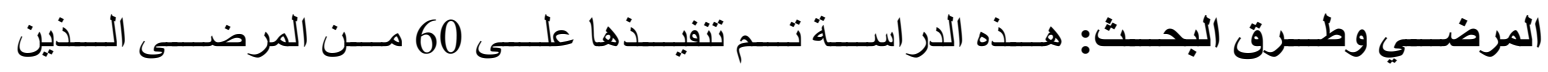

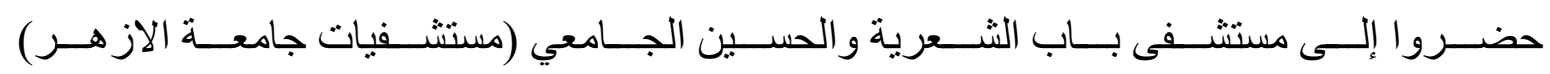

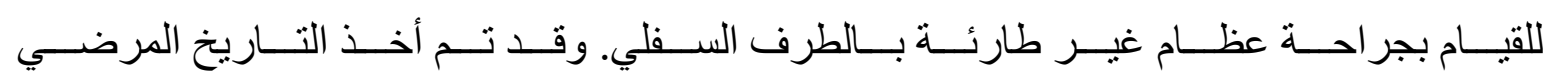

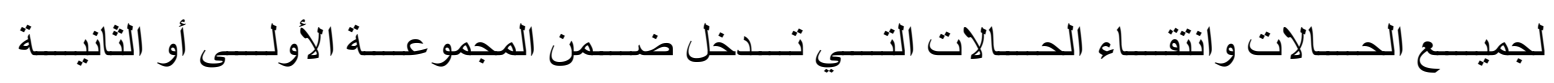

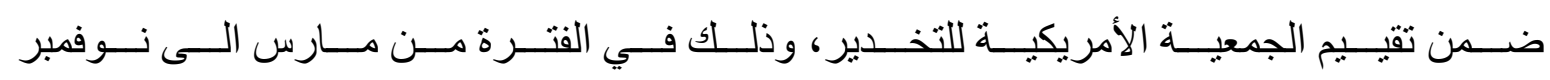
.2020

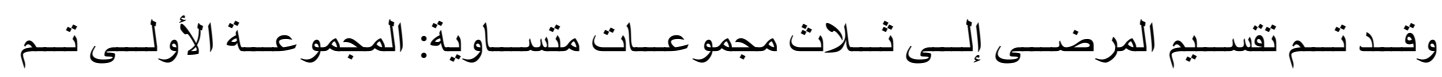

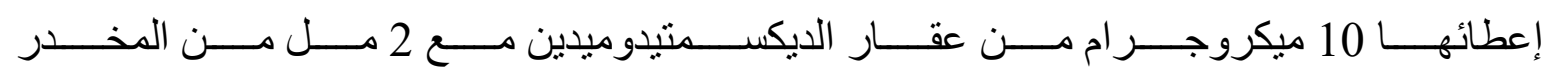

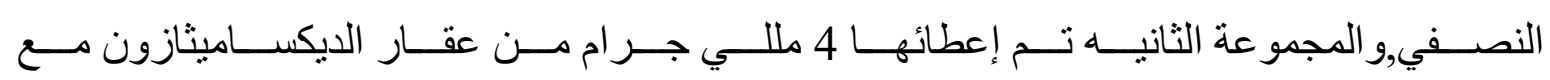

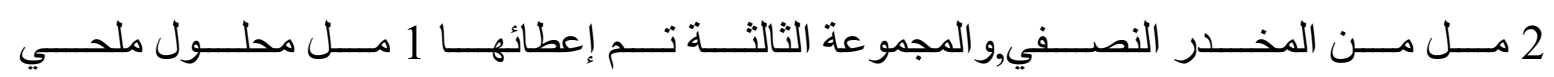
طبيعي مع 2 مل من المخدر النصفي. 


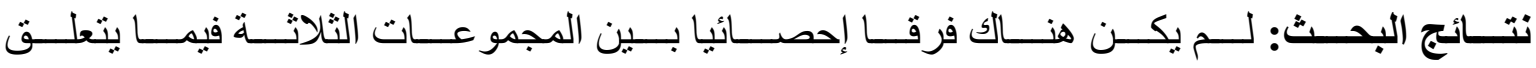

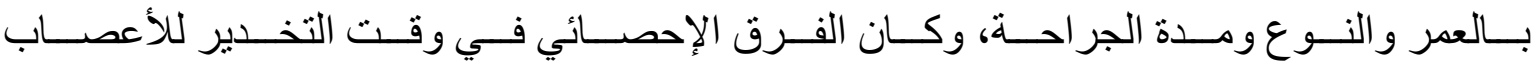

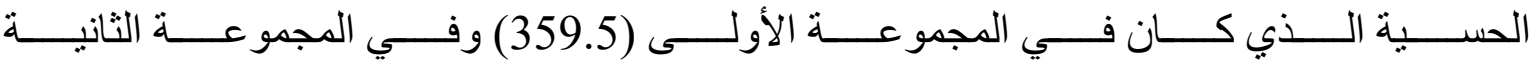

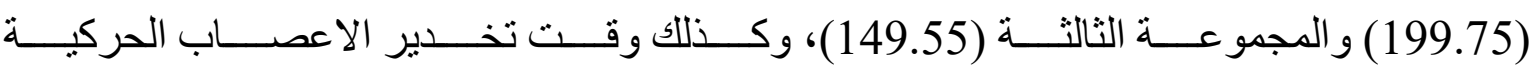

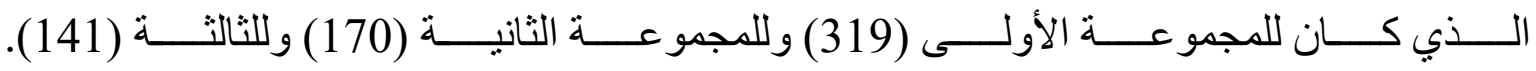

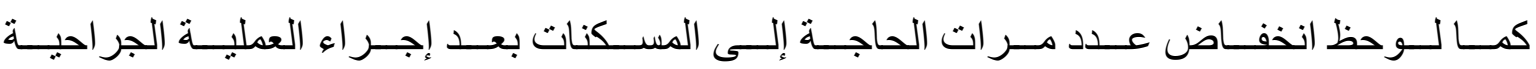

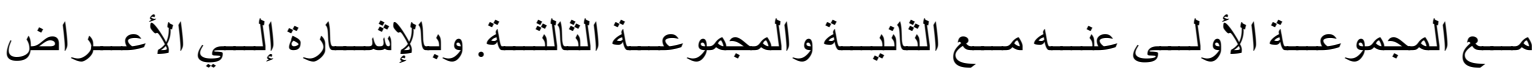

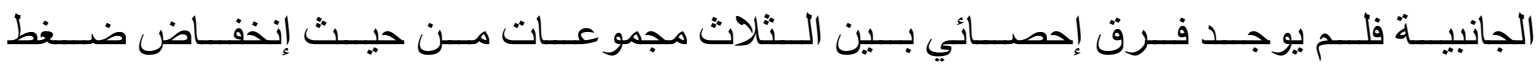
الدم و إنخفاض عدد نبضـات القلب، والاحساس بالقيء، وكذلك القيء.

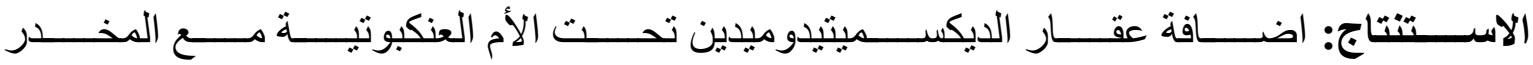

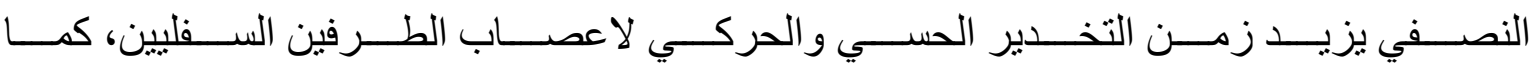

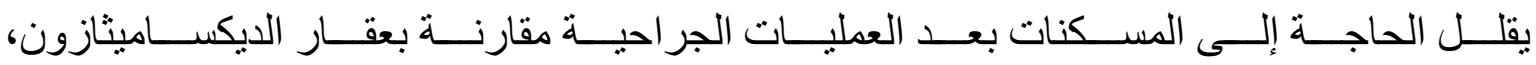

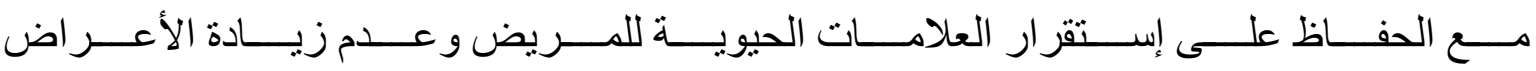
الجانبية في أي من المجمو عات عن الاخرى.

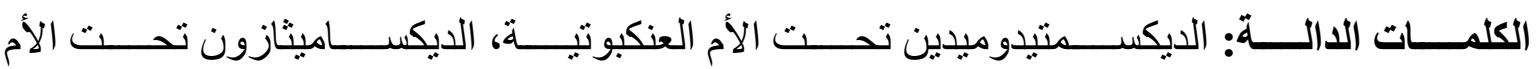
العنكبوثية، التخدير النصفي. 